\title{
RESEARCH
}

\section{High frequency of the erythroid silent Duffy antigen genotype and lack of Plasmodium vivax infections in Haiti}

Thomas A Weppelmann ${ }^{1,2}$, Tamar E Carter ${ }^{3,4,5}$, Zhongsheng Chen ${ }^{3}$, Michael E von Fricken ${ }^{1}, Y_{\text {ves S Victor }}^{6}$, Alexander Existe ${ }^{7}$ and Bernard A Okech ${ }^{1,2^{*}}$

\begin{abstract}
Background: Malaria is a significant public health concern in Haiti where approximately 30,000 cases are reported annually with CDC estimates as high as 200,000. Malaria infections in Haiti are caused almost exclusively by Plasmodium falciparum, while a small number of Plasmodium malariae and an even smaller number of putative Plasmodium vivax infections have been reported. The lack of confirmed $P$. vivax infections in Haiti could be due to the genetic background of native Haitians. Having descended from West African populations, many Haitians could be Duffy negative due to a single nucleotide polymorphism from thymine to cytosine in the GATA box of the promoter region of the Duffy antigen receptor for chemokines (DARC) gene. This mutation, encoded by the FYES allele, eliminates the expression of the Duffy antigen on erythrocytes, which reduces invasion by $P$. vivax. This study investigated the frequency of the $F Y^{E S}$ allele and P. vivax infections in malaria patients with the goal of uncovering factors for the lack of $P$. vivax infections reported in Haiti.
\end{abstract}

Methods: DNA was extracted from dried blood spots collected from malaria patients at four clinic locations in Haiti. The samples were analysed by polymerase chain reaction (PCR) for the presence of the $P$. vivax small subunit ribosomal RNA gene. PCR, sequencing, and restriction enzyme digestion were used to detect the presence of the $F Y^{E S}$ allele. Matched samples were examined for both presence of $P$. vivax and the FYES allele.

Results: No cases of $P$. vivax were detected in any of the samples (0/136). Of all samples tested for the FYES allele, 99.4\% had the $F Y^{E S}$ allele (163/164). Of the matched samples, 99\% had the $F Y^{E S}$ allele (98/99).

Conclusions: In this preliminary study, no cases of $P$. vivax were confirmed by PCR and $99 \%$ of the malaria patients tested carried the $F Y^{E S}$ allele. The high frequency of the $F Y^{E S}$ allele that silences erythroid expression of the Duffy antigen offers a biologically plausible explanation for the lack of $P$. vivax infections observed. These results provide insights on the host susceptibility for $P$. vivax infections that has never before been investigated in Haiti.

Keywords: Plasmodium vivax, Malaria, Hispaniola, Haiti, Duffy antigen receptor for chemokines (DARC), Duffy negative, Genetic susceptibility

\footnotetext{
* Correspondence: bokech@ufl.edu

'Department of Environmental and Global Health, University of Florida, PO

Box 100188, Gainesville, FL 32610, USA

2Emerging Pathogens Institute, University of Florida, 2055 Mowry Rd, P.O.

Box 100009, Gainesville, FL 32610, USA

Full list of author information is available at the end of the article
} 


\section{Background}

Malaria transmission in Haiti is a serious public health concern where approximately 30,000 cases are reported each year with Centers for Disease Control and Prevention (CDC) estimates as high as 200,000 [1]. Over 99\% of malaria infections in Haiti are caused by Plasmodium falciparum, with less than $1 \%$ of cases reported as Plasmodium malariae infections [2-4]. There are even fewer reports of Plasmodium vivax in Haiti, all of which were only detected by microscopy and none confirmed by polymerase chain reaction (PCR) based methodologies [2,5,6]. Since $P$. vivax is responsible for $74 \%$ of all cases of malaria in Central and South America and up to $94 \%$ of cases in Mexico and Central America, the lack of P. vivax infections in Haiti merits further investigation $[1,5,7]$. Besides geographical isolation, host genetic factors could be another reason for the lack of $P$. vivax infections in Haiti. A majority of Haitians are descendants of West African populations, who have a high frequency of individuals that do not express the Duffy antigen receptor for chemokines $(D A R C)$ on their erythrocytes $[8,9]$. The absence of the Duffy antigen on erythrocytes has been shown to reduce or completely prevent $P$. vivax infections [10-14].

The Duffy antigen is a trans-membrane glycoprotein located on red blood cells that contains a N-terminal domain used by $P$. vivax merozoites to invade and infect erythrocytes $[15,16]$. There are two co-dominant alleles $F Y^{A}$ and $F Y^{B}$ that differ by a single nucleotide at amino acid codon 42 , where a change from glycine to aspartic acid results in the expression of the $\mathrm{Fy}^{\mathrm{a}}$ or $\mathrm{Fy}^{\mathrm{b}}$ antigen, respectively [17]. In many African and African-descendent populations the expression of the Duffy antigen is silenced as a result of a single nucleotide polymorphism (SNP) in the GATA box sequence in the $D A R C$ gene promoter region in which a cytosine (C) replaces thymine (T) 46 nucleotides before the erythroid cap site [18-20]. This erythroid silent (ES) genotype, encoded by the $F Y^{E S}$ allele, is responsible for the Duffy negative phenotype expressed by homozygotes that can reach a population frequency of $100 \%$ in native West Africans [9,21].

Neither the reason why $P$. vivax has been so rarely observed in Haitians, nor the prevalence of the erythroid silent Duffy antigen genotype has been investigated in detail. Therefore, this study investigated the frequency of the $F Y^{E S}$ allele and $P$. vivax infections in malaria patients. The information obtained from this study will help clarify the status of $P$. vivax infections in Haiti.

\section{Methods}

\section{Data collection}

Dried blood samples (DBS) were collected by finger prick and blotted on filter paper (FTA cards, Whatman $\odot$ ) in Haiti from May 2010 to August 2012. The samples originated from several clinics including the Blanchard clinic in Port-au-Prince $(n=164)$, Hinche $(n=7)$, Cap-Haitien $(\mathrm{n}=7)$, and Jacmel $(\mathrm{n}=6)$ (Figure 1). Samples from patients at the Blanchard clinic included symptomatic individuals as well as those confirmed by rapid test and/or microscopy to have $P$. falciparum or mixed infections ( $P$. falciparum and P. malariae or P. vivax). Samples from patients at the other three locations were confirmed by microscopy alone. The DBS were transported to the Emerging Pathogens Institute at the University of Florida and archived in dry storage before further genetic analyses as described below.

\section{DNA extraction}

A methanol extraction procedure was used to extract the DNA from the DBS [22]. Three millimetre discs were punched from the DBS, placed inside a PCR tube, and $100 \mu \mathrm{l}$ of absolute methanol was added. The samples were incubated at 25 degrees Celsius $\left({ }^{\circ} \mathrm{C}\right)$ for 15 minutes, the methanol was removed, and the samples were allowed to dry overnight. Once dry, $65 \mu \mathrm{l}$ of nuclease free water was added and heated to $95^{\circ} \mathrm{C}$ for 30 minutes. The samples were centrifuged and then stored at $4^{\circ} \mathrm{C}$ for immediate use or stored at $-20^{\circ} \mathrm{C}$ for future use.

\section{Detection of $P$. vivax by polymerase chain reaction}

A species-specific PCR protocol was used to detect the presence of $P$. vivax in the samples. PCR primers were targeted to detect the $P$. vivax small subunit ribosomal RNA gene and were able to detect low levels of parasites [23]. The forward primer and reverse primer sequences used were $5^{\prime}$ GCAACGCTTCTAGCTTAATC $3^{\prime}$ and 5'ACAAGGACTTCCAAGCCGAAGC 3', respectively. The PCR temperature protocol was as follows: $94^{\circ} \mathrm{C}$ for 5 minutes; $94^{\circ} \mathrm{C}$ for 30 seconds, $58^{\circ} \mathrm{C}$ for 30 seconds, and $72^{\circ} \mathrm{C}$ for 60 seconds for 40 cycles; and $72^{\circ} \mathrm{C}$ for 10 minutes. The expected size of the amplicon was 131 base pairs (bps). All PCR runs included a $P$. vivax positive control obtained from the malaria reagents and resources center (MR4).

\section{PCR and sequencing of the DARC Gene}

A PCR protocol was used to amplify a segment of the $D A R C$ gene that was $329 \mathrm{bps}$ and included the $-46 \mathrm{~T} / \mathrm{C}$ SNP [14]. The forward primer and reverse primer sequences used were 5'CAGGAAGACCCAAGGCCAG 3' and $5^{\prime}$ CCATGGCACCGTTTGGTTCAGG $3^{\prime}$ respectively. The PCR temperature protocol was as follows: $94^{\circ} \mathrm{C}$ for $5 \mathrm{~min} ; 94^{\circ} \mathrm{C}$ for 20 seconds, $62^{\circ} \mathrm{C}$ for 15 seconds, and $72^{\circ} \mathrm{C}$ for 20 seconds for 35 cycles; and $72^{\circ} \mathrm{C}$ for 10 minutes.

Ten of the samples from the malaria patients along with a blood sample from one of the authors of European ancestry were sequenced for the GATA box mutation with the forward and reverse primers described above to identify $-46 \mathrm{~T}$ and $-46 \mathrm{C}$ controls for use in the restriction enzyme digestion of patient samples. DNA was sequenced 


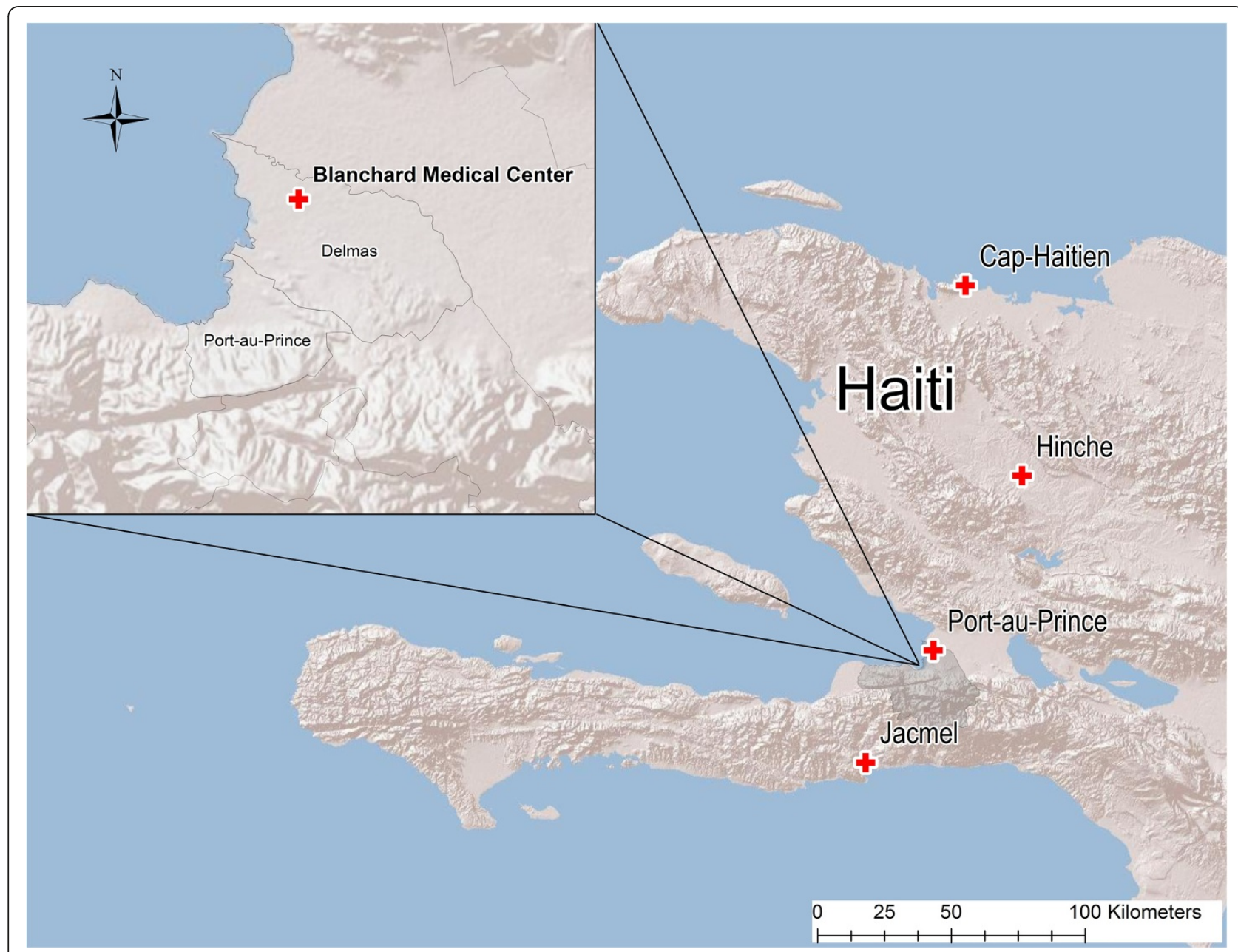

Figure 1 Map of Haiti with clinical origin of dried blood spots.

by the Interdisciplinary Center for Biotechnology Research at the University of Florida using Sanger sequencing. Sequence analysis was accomplished by the examination of the chromatograms with 4Peaks (Mekentosj, Amsterdam, NL) software followed by alignments using Clustal X2 [24].

\section{Restriction fragment length polymorphism of DARC}

Restriction fragment length polymorphism (RFLP) analysis was used to confirm the presence or absence of the -46 T/C SNP [14]. The PCR products were digested overnight with the restriction endonuclease Sty I (New England Biolabs, Ipswich, MA) according to the manufacturer's specifications. After heat inactivation of the enzyme for $10 \mathrm{~min}$ utes at $65^{\circ} \mathrm{C}$, the fragments were stained with ethidium bromide and resolved by gel electrophoresis on a $4 \%$ agarose gel for 2.5 hours at 140 volts.

\section{Results}

The results from the GATA box mutation analysis and the detection of $P$. vivax from the DBS are shown below
(Table 1). No cases of P. vivax were detected by PCR in 136 patient samples tested from the Blanchard clinic. Of the samples tested for the $F Y^{E S}$ allele from the same clinic, 99.4\% (163/164) had the $F Y^{E S}$ allele. Of the matched samples $(\mathrm{n}=99)$ tested for both the presence of P. vivax and the $F Y^{E S}$ allele, no $P$. vivax infections were found and $99 \%$ $(98 / 99)$ had the $F Y^{E S}$ allele. The remaining samples from the other sites were not tested (NT) for $P$. vivax, however $100 \%(20 / 20)$ were positive for the $F Y^{E S}$ allele.

\section{Discussion}

This preliminary study is the first in Haiti to focus on the prevalence of the $F Y^{E S}$ allele and $P$. vivax infections in malaria patients. No $P$. vivax infections were found and $99 \%$ of the malaria patients had the $F Y^{E S}$ allele. The frequency of the $F Y^{E S}$ allele observed in this study could explain the different rates of $P$. vivax Haiti as compared to Central and South America, where the majority of infections are $P$. vivax and the population frequency of the $F Y^{E S}$ allele is rare $[17,25]$. The results from this study are 
Table 1 Prevalence of GATA box mutations and $P$. vivax Infections

\begin{tabular}{|c|c|c|c|c|c|}
\hline \multirow{2}{*}{$\begin{array}{l}\text { Site of sample } \\
\text { Collection }\end{array}$} & \multicolumn{2}{|c|}{$\left(F Y^{E S}\right)$ allele presence } & \multirow[b]{2}{*}{$\%$ Positive } & \multicolumn{2}{|c|}{$P$. vivax presence } \\
\hline & No. tested & No. positive & & No. tested & No. positive \\
\hline Blanchard Clinic & 164 & 163 & 99.4 & 136 & 0 \\
\hline Hinche & 7 & 7 & 100 & 0 & $N T^{*}$ \\
\hline Cap-Haitien & 7 & 7 & 100 & 0 & $N T^{*}$ \\
\hline Jacmel & 6 & 6 & 100 & 0 & $N T^{*}$ \\
\hline Total & 184 & $99.5 \%$ & $99.5 \%$ & 136 & 0 \\
\hline
\end{tabular}

*NT represents samples not tested for the presence of $P$. vivax.

similar to other studies conducted in West African populations, who have between $95-100 \%$ prevalence of the $F Y^{E S}$ allele and almost complete absence of $P$. vivax infections. In a related study in Gambia $(n=1,176)$ where the population had complete penetrance of the Duffy negative phenotype, of the samples positive for the presence of malaria parasites, $94.8 \%$ contained P. falciparum, 3.7\% contained P. malariae, $1.5 \%$ contained Plasmodium ovale, and $0 \%$ contained $P$. vivax [21]. In another study from nine countries in West and Central Africa $(n=2,588)$ where the Duffy negative genotype is estimated to be above 95\%, PCR analysis of blood samples indicated that of samples positive for malaria parasites, only a single case of $P$. vivax was found while $98.5 \%$ contained $P$. falciparum, $8.5 \%$ contained $P$. malariae, and $3.9 \%$ contained $P$. ovale [9].

The high frequency of the $F Y^{E S}$ allele found in this study could be attributed to the West African ancestry of Haitians. Historical records dating back to the 1780s indicate that a large proportion of West Africans brought to the New World during the trans-Atlantic slave trade arrived in Haiti [8]. It is estimated that over $75 \%$ of the total number of enslaved Africans in Haiti came from West and West Central Africa, which have almost exclusively the $F Y^{E S} / F Y^{E S}$ genotype $[8,9]$. This study found only a single patient without the $F Y^{E S}$ allele that may be due to the small proportion of Haitians having French and/or Spanish ancestry or a foreign aid worker, who have much lower population frequencies of the $F Y^{E S}$ allele [18]. Though the French and the Spanish originally colonized Haiti, in 1804 the French departed and the remaining Spanish sequestered themselves eastward to the Dominican Republic. This massive gene flow from West Africa followed by the establishment of Haiti as an independent country could have contributed to high population frequency of Duffy negative individuals [8].

Although the sample size was relatively small, no $P$. vivax DNA was found in any of the patient samples, which is consistent with previous reports of the lack of $P$. vivax in Haiti [2-4]. It is likely that the high prevalence of the $F Y^{E S}$ allele that causes the Duffy negative phenotype may be responsible for the lack of $P$. vivax transmission in Haiti. The samples in this study were obtained from areas that are predominantly of West African ancestry, which are more representative of the ancestry of native Haitians. However, historical reports have indicated $P$. vivax transmission in communes inhabited by higher proportions of people who are of African/European descent that have lower population frequencies of the Duffy negative phenotype [26]. Since $P$. vivax infections have received little attention, it is unknown if such transmission is still occurring in those areas of Haiti. It is likely that low rates of travelers to Haiti from the surrounding $P$. vivax endemic countries in South America may have slowed any potential introductions of $P$. vivax infections into Haiti. Even if introductions were to occur, it would not be likely that $P$. vivax transmission could be sustained because of the high rates of the $F Y^{E S}$ allele in the population. A more extensive study with a larger sample size from multiple sites in Haiti is desirable to confirm these results.

In conclusion, no $P$. vivax infections were confirmed by PCR and the $F Y^{E S}$ allele that results in silenced expression of the Duffy antigen on erythrocytes was found in $99 \%$ of the patients. The high frequency of $F Y^{E S}$ allele could explain the sparse historical evidence of $P$. vivax infections in native Haitians and is attributable to their West African ancestry. Though $P$. vivax malaria is not prevalent and does not represent a significant public health risk in native Haitians, the risk of infection for travellers and foreign aid workers who are Duffy positive remains uncertain.

\section{Competing interests}

The authors declare that they have no competing interests.

\section{Authors' contributions}

TAW carried out the genetic testing for the FYES allele and drafting the manuscript. TC helped conduct the genetic testing for the P. vivax and revision of the manuscript. ZC helped conduct the genetic testing for $P$. vivax. MEV was involved in drafting of the manuscript. VSF, AE aided in the sample collection. BAO conceived, designed and coordinated the study, and helped draft the manuscript. All authors read and approved the final manuscript.

\section{Acknowledgements}

This study was funded by the Department of Defense-Global Emerging Infections Surveillance grant number \#C0607_12_UN to BAO. The authors would like to thank Megan C. Warner for her contributions that ensured the success of this work. 


\section{Author details}

'Department of Environmental and Global Health, University of Florida, PO Box 100188, Gainesville, FL 32610, USA. Emerging Pathogens Institute, University of Florida, 2055 Mowry Rd, P.O. Box 100009, Gainesville, FL 32610, USA. ${ }^{3}$ Genetics Institute, University of Florida, 2033 Mowry Rd, PO Box 103610, Gainesville, FL 32610, USA. ${ }^{4}$ Department of Anthropology, University of Florida, 1112 Turlington Hall, PO Box 117305, Gainesville, FL 32611, USA. ${ }^{5}$ Department of Epidemiology, College of Public Health and Health Professions, University of Florida, PO Box 100231, Gainesville, FL 32611, USA. ${ }^{6}$ Blanchard Clinic, Family Health Ministries Haiti, Terre Noire, Port au Prince, Haiti. ${ }^{7}$ National Public Health Laboratory, Ministry of Public Health and Population (MSPP), Delmas 33, Port au Prince, Haiti.

Received: 14 November 2012 Accepted: 9 January 2013

Published: 24 January 2013

\section{References}

1. Roberts L: Elimination meets reality in Hispaniola. Science 2010, 328:850-851.

2. Lindo JF, Bryce JH, Ducasse MB, Howitt C, Barret DM, Morales JL, Ord R, Burke M, Chiodini PL, Sutherland CJ: Plasmodium malariae in Haitian refugees. Jamaica. Emerg Infect Dis 2007, 13:931-933.

3. Agarwal A, McMorrow M, Arguin PM: The increase of imported malaria acquired in Haiti among US travelers in 2010. Am J Trop Med Hyg 2012, 86:9-10.

4. PAHO: Roll back malaria in meso america: report on the meeting held in the dominican republic with the participation of the central american countries, Haiti, and the dominican republic. Mexico: Pan American Health Organization; 2000

5. PAHO: Regional strategic plan for malaria in the Americas 2006-2010. USA: Pan American Health Organization; 2010:1-85.

6. PAHO: XVIII Pan american sanitary conference XXII regional committee meeting. Washington, DC: World Health Organization; 1970.

7. Mueller I, Galinski MR, Baird JK, Carlton JM, Kochar DK, Alonso PL, del Portillo HA: Key gaps in the knowledge of Plasmodium vivax, a neglected human malaria parasite. Lancet Infect Dis 2009, 9:555-566.

8. Falola T, Roberts $\mathrm{K}$, Childs M: The yoruba diaspora in the atlantic world. Bloomington, IN: Indiana University Press; 2004.

9. Culleton RL, Mita T, Ndounga M, Unger H, Cravo PV, Paganotti GM, Takahashi N, Kaneko A, Eto H, Tinto H, Karema C, D'Alessandro U, do Rosario V, Kobayakawa T, Ntoumi F, Carter R, Tanabe K: Failure to detect plasmodium vivax in west and central africa by PCR species typing. Malar J 2008, 7:174.

10. Zimmerman PA, Woolley I, Masinde GL, Miller SM, McNamara DT, Hazlett F, Mgone CS, Alpers MP, Genton B, Boatin BA, Kazura JW: Emergence of $F Y^{*} A^{\text {null }}$ in a Plasmodium vivax-endemic region of Papua New Guinea. Proc Natl Acad Sci USA 1999, 96:13973-13977.

11. Chaudhuri A, Polyakova J, Zbrzezna V, Pogo AO: The coding sequence of Duffy blood group gene in humans and simians: restriction fragment length polymorphism, antibody and malaria parasite specificities, and expression in nonerythroid tissues in Duffy-negative individuals. Blood 1995, 85:615-621.

12. Chaudhuri A, Polyakova J, Zbrzezna V, Williams K, Gulati S, Pogo AO: Cloning of glycoprotein D cDNA, which encodes the major subunit of the Duffy blood group system and the receptor for the Plasmodium vivax malaria parasite. Proc Natl Acad Sci USA 1993, 90:10793-10797.

13. Grimberg BT, Udomsangpetch R, Xainli J, McHenry A, Panichakul T, Sattabongkot J, Cui L, Bockarie M, Chitnis C, Adams J, Zimmerman PA, King $\mathrm{CL}$ : Plasmodium vivax invasion of human erythrocytes inhibited by antibodies directed against the Duffy binding protein. PLoS Med 2007, 4:e337.

14. Kasehagen $L$, Mueller I, Kiniboro B, Bockarie MJ, Reeder JC, Kazura JW, Kastens W, McNamara DT, King CH, Whalen CC, Zimmerman PA: Reduced Plasmodium vivax erythrocyte infection in PNG Duffy-negative heterozygotes. PLoS One 2007, 2:e336.

15. VanBuskirk KM, Sevova E, Adams JH: Conserved residues in the Plasmodium vivax Duffy-binding protein ligand domain are critical for erythrocyte receptor recognition. Proc Natl Acad Sci USA 2004, 101:15754-15759.
16. Michon P, Stevens JR, Kaneko O, Adams JH: Evolutionary relationships of conserved cysteine-rich motifs in adhesive molecules of malaria parasites. Mol Biol Evol 2002, 19:1128-1142.

17. King $\mathrm{CL}$, Adams JH, Xianli J, Grimberg BT, McHenry AM, Greenberg LJ, Siddiqui A, Howes RE, da Silva-Nunes M, Ferreira MU, Zimmerman PA: $\mathrm{Fy}^{\mathrm{a}} / \mathrm{Fy}^{\mathrm{b}}$ antigen polymorphism in human erythrocyte Duffy antigen affects susceptibility to Plasmodium vivax malaria. Proc Natl Acad Sci USA 2011, 108:20113-20118.

18. Tournamille C, Colin Y, Cartron JP, Le Van Kim C: Disruption of a GATA motif in the Duffy gene promoter abolishes erythroid gene expression in Duffy-negatie individuals. Nat Genet 1995, 10:224-228.

19. Cavasini CE, de Mattos LC, D'Almedia Couto AAR, D'Almedia Couto VSC, Gollino Y, Moretti $\amalg$, Bonini-Domingos CR, Rossit ARB, Castilho L, Machado RLD: Duffy blood group gene polymorphisms among malaria vivax patients in four areas of the Brazilian Amazon region. Malar J 2007, 6:167.

20. Castilho L, Rios M, Pellegrino J, Saad STO, Costa FF, Reid ME: A novel FY allele in Brazilians. Vox Sang 2004, 87:190-195.

21. Welch SG, McGregor IA, Williams K: The duffy blood group and malaria prevalence in gambian west Africans. Trans R Soc Trop Med Hyg 1977, 71:295-296.

22. Bereczky S, Martensson A, Gil JP, Farnert A: Short report: rapid DNA extraction from archive blood spots on filter paper for genotyping of Plasmodium falciparum. AmJTrop Med Hyg 2005, 72:249-251.

23. Hang VT: Screening donor blood for malaria by polymerase chain reaction. Trans R Soc Trop Med Hyg 1995, 59:124-128.

24. Thompson JD, Gibson TJ, Plewniak F, Jeanmougin F, Higgins DG: The CLUSTAL X windows interface: flexible strategies for multiple sequence alignment aided by quality analysis tools. Nucleic Acids Res 1997, 25:4876-4882

25. Guerra CA, Snow RW, Hay SI: Mapping the global extent of malaria in 2005. Trends Parasitol 2006, 22:353-358.

26. Mason J: Development of the Haiti malaria eradication programme, World Health Organization technical document. WHO/Mal/68.665; 1968.

doi:10.1186/1475-2875-12-30

Cite this article as: Weppelmann et al: High frequency of the erythroid silent Duffy antigen genotype and lack of Plasmodium vivax infections in Haiti. Malaria Journal 2013 12:30.

\section{Submit your next manuscript to BioMed Central and take full advantage of:}

- Convenient online submission

- Thorough peer review

- No space constraints or color figure charges

- Immediate publication on acceptance

- Inclusion in PubMed, CAS, Scopus and Google Scholar

- Research which is freely available for redistribution 